\title{
EARLY FLOWERS OF PRIMULOID ERICALES FROM THE LATE CRETACEOUS OF PORTUGAL AND THEIR ECOLOGICAL AND PHYTOGEOGRAPHIC IMPLICATIONS
}

\author{
ELSE MARIE FRIIS ${ }^{1,2, *}$, PETER R. CRANE ${ }^{3,4}$, KAJ RAUNSGAARD PEDERSEN' \\ ${ }^{1}$ Department of Geoscience, University of Aarhus, Høegh-Guldbergs Gade 2, DK-8000 Aarhus C, Denmark; \\ e-mail: else.marie.friis@geo.au.dk,krp@geo.au.dk. \\ 2 Department of Palaeobiology, Swedish Museum of Natural History, Box 50007, SE-104 05 Stockholm, Sweden. \\ ${ }^{3}$ Oak Spring Garden Foundation, 1776 Loughborough Lane, Upperville, Virginia 20184, USA; e-mail: peter@osgf.org. \\ ${ }^{4}$ Yale School of the Environment, Yale University, New Haven, Connecticut 06511, USA. \\ ${ }^{*}$ corresponding author
}

Friis, E. M., Crane, P. R., Pedersen, K. R. (2021): Early flowers of primuloid Ericales from the Late Cretaceous of Portugal and their ecological and phytogeographic implications. - Fossil Imprint, 77(2): 214-230, Praha. ISSN 2533-4050 (print), ISSN 2533-4069 (on-line).

\begin{abstract}
A distinctive feature of the major eudicot diversification that occurred through the Late Cretaceous is the unequivocal presence of Cornales and diverse Ericales. Here we describe well-preserved fossil flowers from the Mira locality in western Portugal, of Campanian-Maastrichtian age, that we assign to a new extinct genus of Ericales with two new species; Miranthus elegans gen. et sp. nov. and Miranthus kvacekii sp. nov. The fossil flowers are pedicellate, structurally bisexual, actinomorphic, pentamerous and isomerous, with five narrowly triangular persistent calyx lobes, a five-lobed corolla, five antepetalous stamens, five staminodes alternating with the petals and a semi-inferior, unilocular ovary. The ovary consists of five carpels and has a raised nectariferous ring with stomata-like openings above the insertion of the perianth, and a long five-angled style. A key feature, which confirms a relationship with Primulaceae s. 1., is the free, central dome-shaped placenta that bears numerous, densely spaced ovules. The ovary matures into a capsule containing many, minute, reticulate seeds. Flowers of Miranthus are especially similar to those of extant Samolus, a genus of about twelve species that is sister group to other genera of subfamily Theophrastoideae and that has a disjunct distribution mainly in the Southern Hemisphere. Miranthus also appears to have grown in environments influenced by marine conditions, an ecological preference also seen in Samolus. Miranthus expands the diversity of Ericales known from the Late Cretaceous, and together with previously described fossils provides further evidence that the diversification of Ericales was already underway by the Campanian-Maastrichtian stages of the Late Cretaceous.
\end{abstract}

Key words: Campanian, Ericales, fossil flowers, Maastrichtian, Primulaceae s. 1., SRXTM, synchrotron radiation X-ray tomographic microscopy

Received: September 8, 2021 | Accepted: November 19, 2021| Issued: December 24, 2021

\section{Introduction}

Investigations of small coalified and charcoalified flowers, fruits and seeds from Cretaceous strata, combined with information from fossil leaves as well as extensive palynological data, document a massive and rapid diversification of eudicots, beginning in the late Barremianearly Aptian and continuing through the Albian into the Late Cretaceous (e.g., Doyle and Hickey 1976, Hickey and Doyle 1977, Crane and Lidgard 1989, Crane et al. 1995, Friis et al. 2006a, 2011, Herendeen et al. 2017). Central in this diversification is the expansion and diversification of core eudicots (Crepet 1996, Magallón et al. 1999, Crepet et al. 2004, Friis et al. 2006a, b, 2011, 2016). Of the two major groups of core eudicots, rosids are well-represented in Late Cretaceous fossil flower and fruit assemblages by early forms of uncertain relationship (Friis et al. 2016) as well as early Fabales (Manchester et al. 2018), and also by species belonging to extant Fagales, including the diverse and widespread Normapolles group, a complex of extinct plants related to Betulaceae-Casuarinaceae-Ticodendraceae and Juglandaceae-Myricaceae-Rhoipteleaceae (Friis 1983, Knobloch and Mai 1986, Sims et al. 1999, Schönenberger et al. 2001, Friis et al. 2003, 2006b). Asterids are also well-represented among fossil flowers and fruits from the Late Cretaceous, but are mainly restricted to Cornales and Ericales, two clades that appear to have diverged early from other asterids. In contrast, euasterids, which include several of the most species rich extant angiosperm lineages, such 
as Apiales, Lamiales and Rubiales, have a poor Cretaceous record, suggesting that they either evolved later, or were subordinate in Late Cretaceous vegetation.

The Ericales are known from more than 35 fossil species of flowers, fruits and seeds from Late Cretaceous sediments in Europe and North America (e.g., Friis 1985, Knobloch and Mai 1986, Nixon and Crepet 1993, Keller et al. 1996, Schönenberger and Friis 2001, Martínez-Millán et al. 2009, Friis et al. 2011, Schönenberger et al. 2012, Crepet et al. 2013, 2018). Some of these fossil species are based on fragmentary or limited material, such as fruits or isolated seeds, and while their relationship to Ericales appears wellfounded, their systematic position within the order is not always clear. However, several highly informative flowers, as well as isolated seeds with characteristic morphology and seed coat structure, can be placed unequivocally in extant families (e.g., Parasaurauia allonensis J.A.Keller, Herend. et P.R.Crane, Actinidiaceae) and in some cases even in extant genera (e.g., Eurya crassitesta ERw.KNOBLOCH, Pentaphylaceae). The available palaeobotanical data, taken as a whole, indicates that three of the major lineages of the Ericales; the Pentaphylaceae-Sladeniaceae clade, the Theaceae-Symplocaceae-Styracaceae-Diapensiaceae clade and the Sarraceniaceae-Actinidiaceae-RoridulaceaeClethraceae-Cyrillaceae-Ericaceae clade, were well-established and diverse in the Late Cretaceous, although we exclude the highly speculative report of a Sarracenia-like pitcher plant, Archaeamphora longicerva H.Q.LI, from the Early Cretaceous Yixian Formation of northeastern China (Li 2005), which was based on poorly preserved material.

In this paper, we expand the Late Cretaceous fossil record of Ericales with the description of a distinctive new genus and two new species based on minute coalified fossil flowers that can be assigned securely to the order. As with other coalified plant mesofossils (e.g., Friis et al. 2007, 2014, 2015), the application of synchrotronradiation X-ray tomographic microscopy (SRXTM) reveals astonishingly fine details, including features of placentation and ovule attachment, which allow the fossils to be placed unequivocally among the Primulaceae s. 1.

\section{Material and methods}

The fossil flowers studied here were collected between 1989 and 1992 by EMF and KRP from the Mira locality $\left(40^{\circ} 25^{\prime} \mathrm{N}, 08^{\circ} 44^{\prime} 15^{\prime \prime} \mathrm{W}\right)$, an abandoned clay pit in the southern outskirts of the small town of Mira, about $25 \mathrm{~km}$ south of Aveiro, in the District of Coimbra, western Portugal. The pit is no longer available for collection, but the sediments collected include dark clays and silts as well as greenish, glauconitic clays with abundant pyrite and shells of invertebrate fossils that indicate deposition under marine influence. The plant bearing clay is assigned to the "Argilas de Vagos", which is dated as of Campanian-Maastrichtian age (Carta Geologica de Portugal 16C Vagos; Barbosa et al. 1981) and corresponds to the informal formation "Argilas de Aveiro" / "Arenitos e Argilas de Aveiro" (Bernardes and Corrochano1987). These sediments are interpreted as having been deposited in lowlying coastal plains and estuaries with occasional connections to the open sea (Antunes and Broin 1988, Dinis et al. 2008).
A Late Campanian age is also inferred for the fully marine sequence immediately west of Mira based on ammonites and other marine fossils (Beauvais et al. 1975). The plant fossils described here come from samples of a dark clay collected at the former entrance to the clay pit, and from samples collected from a greenish, glauconitic and pyritic clay in the southern part of the quarry (Friis et al. 2011).

Mesofossil assemblages from the Mira locality contain diverse angiosperms (Friis et al. 2010), including several rosid taxa, of which three have been described formally. Esgueiria miraensis E.M.Fris, K.R.Pedersen et P.R.CRANE (Friis et al. 1992) is of myrtalean (combretaceous) affinity, while Normanthus miraensis SchÖNENB., K.R.PEDERSEN et E.M.FriIs (Schönenberger et al. 2001) and Endressianthus miraensis E.M.FriIs, K.R.PedERSEN et SchönEnb. (Friis et al. 2003) both belong to the Normapolles complex (Fagales). The Mira assemblage is also interesting for the presence of two monocot taxa, Spirematospermum sp. (Zingiberales) and seeds of Araceae (Friis et al. 2006a) as well as several undescribed monocot flowers.

Mesofossil assemblages from the Mira locality were isolated from the sediments and cleaned of adhering mineral matrix following standard techniques (see Friis et al. 2011, 2018). For SEM, specimens were mounted on aluminium stubs with nail polish, coated with gold (thickness not measured), and studied using Jehol JSM 840 (S101267, S101268) and Phillips 515 scanning electron microscopes (S100732, S101266) or a Hitachi S-4300 field emission microscope (S153144-S153146, S170106, S170123, S170125, S170155) at the Swedish Museum of Natural History.

Ten specimens (S100732, S153144-S153146, S156331, S170106, S170123, S170155, S170157, S266059) were studied using synchrotron-radiation X-ray tomographic microscopy (SRXTM) at the TOMCAT Beamline, Swiss Light Source at the Paul Scherrer Institute, Villigen, Switzerland (Stampanoni et al. 2006). Specimens S153144 S153146 were analysed using phase contrast imaging at $20 \mathrm{keV}$. The other specimens were studied using absorption imaging at $10 \mathrm{keV}$. All specimens were analysed with rotation over $180^{\circ}$ and most specimens were examined using a $10 \times$ objective with isotropic voxel size of $0.74 \mu \mathrm{m}$ (S100732, S153144-S153146, S170123, S170155, S170157) or $0.65 \mu \mathrm{m}$ (specimens S15633, S170106, S266059). Specimens S170123 and S170106 were studied using 20× objective with isotropic voxel size of $0.37 \mu \mathrm{m}$ (S170123) or $0.325 \mu \mathrm{m}$ (S170106). For details of SRXTM work on Cretaceous plant mesofossils at TOMCAT see Friis et al. (2014). Data derived from the SRXTM scans were analysed and manipulated using Avizo software (9.1.1-9.5; Thermo Scientific, Waltham, MA, USA) for computed tomography. Photoshop CS5 Adobe (San Jose, CA, USA) was used to create an even black background for SEM images and to label SRXTM images.

An assessment of the phylogenetic position of the fossils was performed using Mesquite software version 3.2 (Maddison and Maddison 2017) using the Parsimony Ancestral State feature with all characters treated as unordered. Taxa and morphological character states were selected from the comprehensive study of relationships among extant primuloids by Anderberg and Ståhl (1995) 
based on morphology, and include representatives from the immediate sister groups to Primulaceae (Ebenaceae: Diospyros spp., Sapotaceae: Manilkara zapota (L.) P.Royen) as well as genera selected to represent the four subfamilies of the Primulaceae (Maesoideae: Maesa subg. Maesa, Theophrastoideae: Samolus valeradi L., Theophrasta americana L., Clavija spp., Primuloideae: Douglasia nivalis Lindl., Soldanella alpina L., Primula veris L., Cortusa matthioli L., Myrsinoideae: Cyclamen coum MiLler, Lysimachia glutinosa Rock, Ardisiandra sibthorpioides Hook.F., Anagallis monellii L., Myrsine africana L.). A backbone tree was constructed for these taxa based on topologies supported by molecular data for Ericales (Rose et al. 2018) and for Primulaceae (Morozowska et al. 2020). The number of character state changes for each potential position of Miranthus was recorded by linking the fossils manually to all possible branches of the backbone tree.

All specimens are deposited in the palaeobotanical collections of the Swedish Museum of Natural History, Stockholm (S). Raw data from the SRXTM analyses are available at the PSI Public Data Repository, Paul Scherrer Institute, Villigen, Switzerland (Friis et al. 2021). The names assigned to the new genus and species described here, are each registered with a unique registry number in the Plant Fossil Names Registry, which is hosted and operated by the National Museum, Prague for the International Organisation of Palaeobotany (IOP).

\section{Characters scored for the phylogenetic analyses}

Characters scored for extant primuloid flowers and fossils of Miranthus are based on the morphological dataset (characters 24-82) of Anderberg and Ståhl (1995). Thirty characters were scored for the fossil flowers. 25: Pedicel (0) without paired bracteoles. 26: Flower (1) perigynous. 27: Flowers (0) homostylous. 28: Flowers (1) bisexual. 29: Flowers (2) haplostemonous with the functional stamens opposite the corolla lobes. 30: Perianth (0) 5-merous. 33: Corolla (1) with staminodes. 34: Corolla aestivation (0) imbricate or quincuncial. 37: Corolla texture (1) thin. 38: Sepals (1) united, often cup-shaped. 40: Petals (0) entire. 41: Petals (0) longer than sepals or subequal. 42: Petals (1) lanceolate-ovate, more or less acute, and usually distinctly longer than wide. 45: Flower (3) with somatic gynoecium nectaries. 46: Anther filaments (0) without long septate trichomes. 47: Anther filaments (0) free from each other. 49: Anther filaments (0) eglandular. 57: Anthers (0) not forming a cone. 61: Pollen (0) 3-, 4-, or 5-colporate, or colporoidate. 62: Style (0) included, shorter than or slightly longer than the anthers. 64: Style (1) entire. 66: Fruit (2) a capsule. 67: Fruit (0) normally many-seeded. 68: Fruit opening (1) with teeth or valves. 69: Fruit (1) globose to subglobose. 70: Placenta (1) free central. 71: Ovules (0) densely set on placenta. 72: Ovules (1) bitegmic. 73: Ovules (0) not immersed in the placenta. 74. Ovules (0) in two or more series, usually many.

\section{Systematic palaeobotany}

\author{
Subdivision Angiospermae LiNDL., 1830 \\ Order Ericales Bercht. et J.Presl, 1820
}

Family Primulaceae BATSCH ex BoRKH., 1774 nom. cons.

\section{Genus Miranthus E.M.FriIs, P.R.Crane et K.R.Pedersen gen. nov.}

Type. Miranthus elegans E.M.FriIS, P.R.Crane et K.R.Pedersen gen. et sp. nov.

Plant Fossil Names Registry Number. PFN002665 (for new genus).

E t y m o log y. From the village of Mira close to where the fossils were collected.

D i a g n o s is . Flowers pedicellate, structurally bisexual, actinomorphic, pentamerous and isomerous. No bracteoles present immediately under calyx. Sepals narrowly triangular, basally fused, persistent. Petals ovate, longer than sepals. Stamens opposite corolla lobes; staminodes alternating with the corolla lobes. Ovary semi-inferior, unilocular, of five carpels; single style long with a wide stylar canal that is five-angled in cross-section. Apical portion of ovary with a slightly raised nectariferous ring and stomata-like openings. Placentation free, central. Ovules numerous and densely spaced on the placenta, but not immersed. Ovules anatropous and bitegmic. Fruit a capsule. Seeds many, minute, angular, with reticulate surface.

Comments on the genus. The combination of distinctive floral features clearly places Miranthus in the Primulaceae s. 1. and all features recorded for the fossil material are known also for the extant primuloid genus Samolus L. (subfamily Theophrastoideae). However, Miranthus also closely resembles flowers of other members of the subfamily, and because not all floral features of the fossil taxon are sufficiently well-known we refrain from assigning the fossils to an extant genus.

To our knowledge there are no comparable flowers recorded from the fossil record. Three possible primuloid flowers from the Cainozoic Baltic amber, Berendtia primuloides Göpp., B. rotata Conw. and Myrsinopsis succinea Conw. are fragmentary, and are preserved only as dispersed, sympetalous corollas with attached stamens (Göppert and Berendt 1845, Conwentz 1886).

\section{Miranthus elegans E.M.FriIs, P.R.CRANE et K.R.Pedersen sp. nov. Text-figs 1-6}

H o l o ty p e. S170155 (Mira sample 100; figured Textfigs $1 \mathrm{a}, 4 \mathrm{c}, \mathrm{d}, 5 \mathrm{c}, \mathrm{d})$.

Paratypes. S170106 (Mira sample 99), S101263, S101264, S101266-S101268, S153144-S153146, S154535S154538, S170123, S170125, S266059 (Mira sample 100), S100732 (Mira sample 105).

Plant Fossil Names Registry Number. PFN002666 (for new species).

Rep os it ory. Palaeobotanical Collections, Swedish Museum of Natural History, Stockholm, Sweden (S).

E t y m o log y. From the elegant shape of the pedicellate flower.

Type locality. Mira $\left(40^{\circ} 25^{\prime} \mathrm{N}, 08^{\circ} 44^{\prime} 15^{\prime \prime} \mathrm{W}\right)$, about $25 \mathrm{~km}$ south of Aveiro, District of Coimbra, Portugal. 

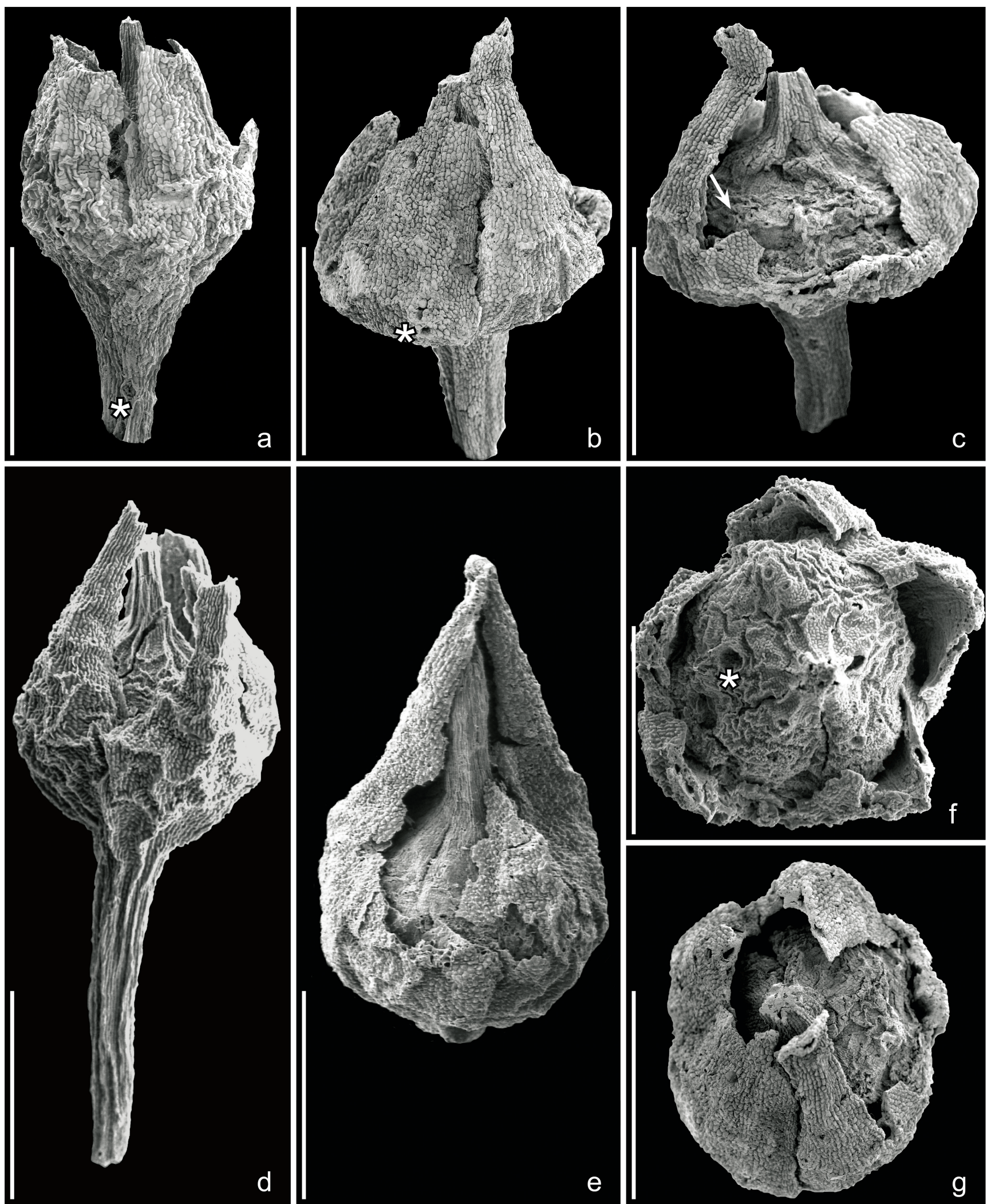

e

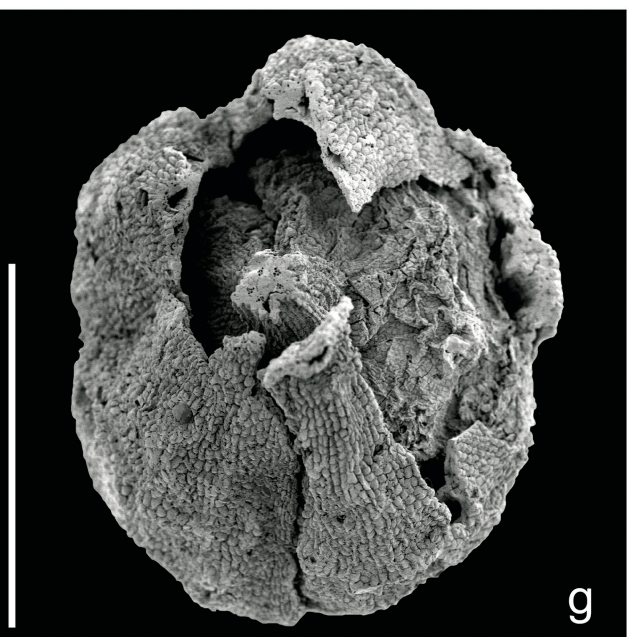

Text-fig. 1. SEM images of flowers of Miranthus elegans gen. et sp. nov.; Mira locality, Portugal. a, b: Flowers in lateral view showing elongated pedicel, narrowly triangular sepals and elongated protruding style (a); note the large openings in the floral tissue and pedicel (asterisks) interpreted as schizogenous secretory cavities. c: Flower in lateral view with portion of the calyx missing exposing the ovary wall and slightly raised nectariferous ring with probable stomata-like secretory structures (arrow). d: Flower in lateral view showing long pedicel and three of the five tepals; note the elongated narrowly triangular form of the sepals. e: Flower in oblique lateral view with portion of the calyx missing exposing the ovary and elongated style. $f$, g: Flowers in apical view showing the bases of five sepals (f) and apex of the five-parted ovary; note larger openings in the floral tissue (asterisk) interpreted as schizogenous secretory cavities. Specimens, Mira 100-S170155 (a, holotype), Mira 100-S153145 (b, c, g), Mira 100S101267 (d), Mira 105-S100732 (e), Mira 100-S101268 (f). Scale bars = $600 \mu \mathrm{m}(\mathrm{a}-\mathrm{g})$. 

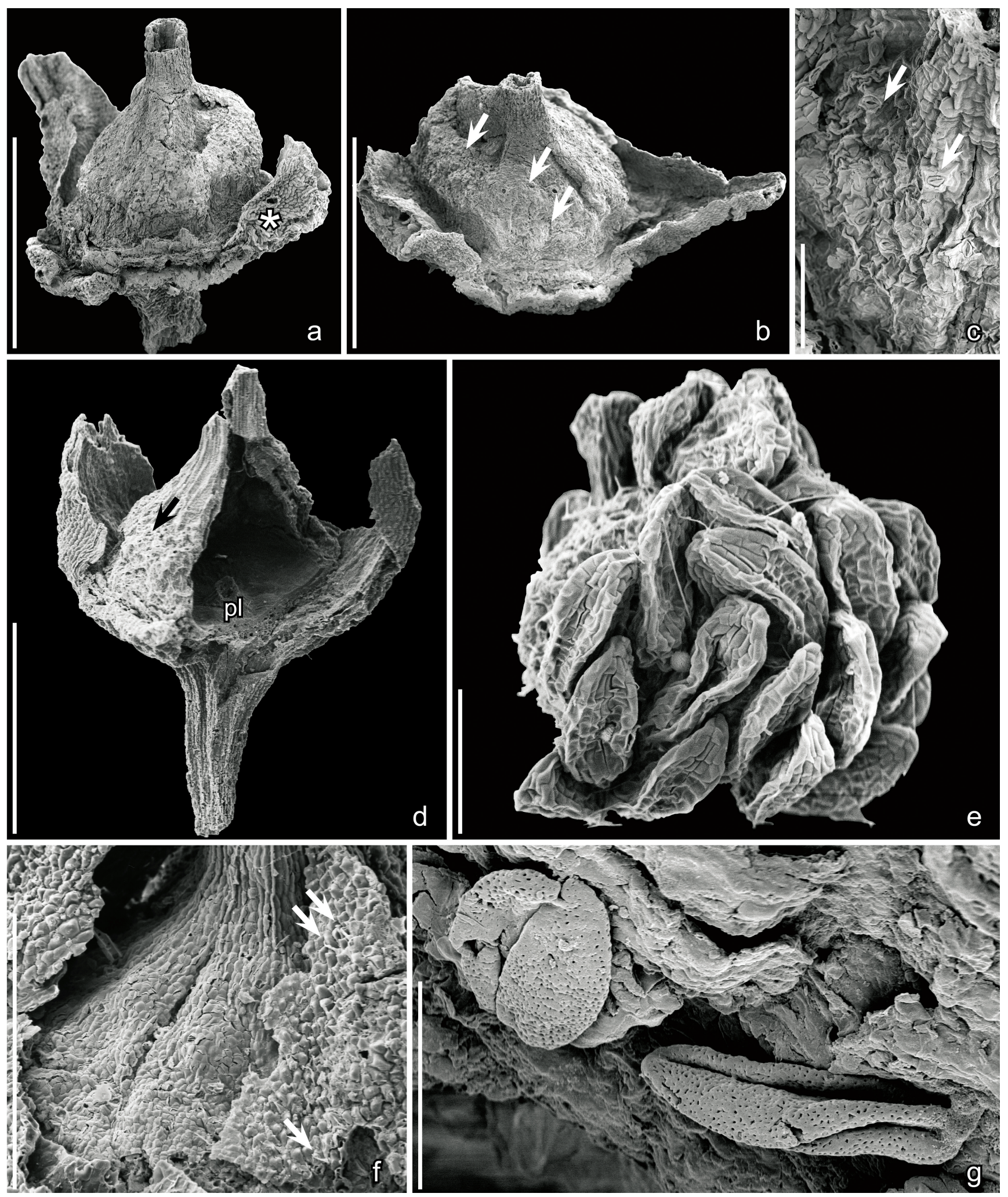

Text-fig. 2. SEM images of Miranthus elegans gen. et sp. nov.; Mira locality, Portugal. a, b: Flowers in oblique lateral view showing remains of calyx and slightly semi-inferior ovary with elongated apical style (a); note larger openings in the floral tissue (asterisk) interpreted as schizogenous secretory cavities and the stomata-like secretory structures on the upper portion of the ovary (arrows) that are interpreted as nectariferous (b). c: Detail of ovary surface showing secretory stomata-like structures (arrows). d: Flower in lateral view showing fragmentary calyx and broken slightly semi-inferior ovary with secretory stomata-like structures; note the point of attachment of the central placenta ( $\mathrm{pl}$ ). e: Cluster of seeds removed from the ovary in (d) showing reticulate surface. f: Outer (abaxial) surface of calyx lobe showing the slightly pointed papillae and scattered, fine trichomes (arrows). g: Triaperturate pollen grains from the ovary surface. Specimens, Mira 100-S153146 (a, b), Mira 100-S170155 (c), Mira 100-S101266 (d, e), Mira 105-S100732 (f), Mira 100-S170125 (g). Scale bars = $600 \mu \mathrm{m}$ (a, b, d), $300 \mu \mathrm{m}$ (f), $100 \mu \mathrm{m}$ (c, e), $10 \mu \mathrm{m}$ (g). 

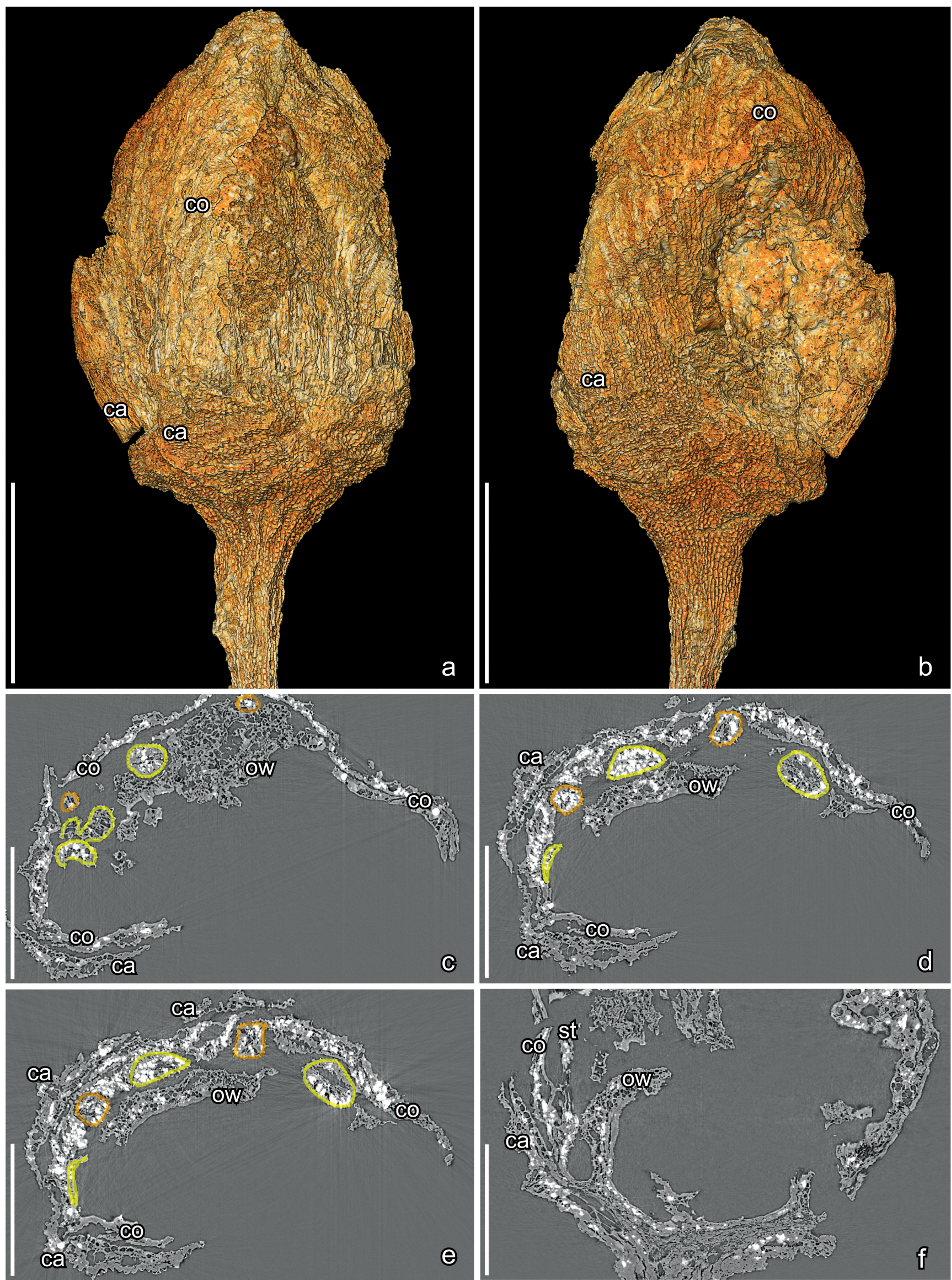

Text-fig. 3. SRXTM images of Miranthus elegans gen. et sp. nov.; Mira locality, Portugal. a, b: Volume renderings of flower bud in two different lateral views showing long pedicel, distinct calyx (ca) with almost equiaxial epidermal cells and corolla (co) with nearly smooth surface. c-e: Transverse sections (c, orthoslice xy1500; d, orthoslice xy1760; e, orthoslice xy1850) through flower bud at levels below the anthers showing stamen filaments (yellow) opposite the corolla lobes (co) and smaller staminodes (orange) 
Type stratum and age. "Argilas de Vagos", Late Cretaceous (Campanian/Maastrichtian).

Diagnosis. As for the genus with the following addition. Epidermis of pedicel and outer (abaxial) epidermis of calyx composed of cells that each have a central pointed papilla. Trichomes scattered and thin.

Dimensions. Length of flower without pedicel and corolla: $0.8-1.0 \mathrm{~mm}$; diameter: $0.7-1.0 \mathrm{~mm}$. Length of flower bud with corolla and without pedicel: $1.5 \mathrm{~mm}$.

Description and comments on the species. The fossil flowers were briefly described and illustrated by Friis et al. (2010,2011), but not formally named. More material has subsequently been discovered, including a small, informative flower bud. In most flowers the corolla and androecium have been shed (Text-figs 1a-g, 2a-d) and the flowers are probably fossilized at a post-anthetic stage. The flower bud has remains of corolla and stamens preserved (Text-fig. 3a-f), but unfortunately, internal structures, including the ovary, ovules and parts of the androecium, are not well preserved. These internal structures were partially destroyed during fossilization and are only preserved on one side of the flower, which complicates interpretations of their organisation. The flower bud is assigned to the same species as the post-anthetic flowers based on features of the calyx. A second flower bud from the Mira mesofossil flora is described as a separate species, Miranthus kvacekii, based on epidermal differences from Miranthus elegans.

The flowers are borne on a long, slender pedicel (Textfigs 1a-d, 2d, 3a, b) and lack bracts or bracteoles immediately below the calyx. The pedicel is up to about $0.9 \mathrm{~mm}$ long (Text-fig. 1d). All of the fossil flowers are isolated and there is no information on inflorescence structure, or how the pedicel may have been attached to the plant.

The flowers are structurally bisexual, actinomorphic, pentamerous and isomerous, about $0.8-1.0 \mathrm{~mm}$ long, excluding the pedicel and corolla, and $0.7-1.0 \mathrm{~mm}$ in diameter. Including the corolla, but excluding the pedicel, the flower bud is about $1.5 \mathrm{~mm}$ long. The calyx is persistent and consists of five imbricate sepals in a single whorl that are fused at the base (Text-figs 1a-g, 5a, b). The sepals are narrowly triangular, with the free portion up to about $0.9 \mathrm{~mm}$ long, which tapers into a long tip (Text-fig. 1a-g). Each sepal is supplied by three distinct vascular bundles, each of which typically appears as a hollow space in transverse sections (Text-figs 5a, 6a, b). In some specimens, minor vascular bundles are seen close to the sepal margins. The epidermis of the pedicel, and the abaxial (outer) epidermis of the calyx, is covered by a thick cuticle. The epidermal cells are small, almost equiaxial, thick-walled and typically with a pointed papilla that gives the surface a faint verrucate to spiny appearance. Similar epidermal features are also observed on the outer surface of the young ovaries (Text-figs 1a-g, 2f, $3 \mathrm{c}-\mathrm{e}, 5 \mathrm{a}-\mathrm{d}, 6 \mathrm{a})$. Very slender trichomes occur scattered on the outer surface of the sepals (Text-fig. $2 \mathrm{f}$ ). The epidermal cells of the adaxial (inner) epidermis of the calyx lobes are small, equiaxial, thin-walled and covered with a thin cuticle (Text-fig. 3c-e). The calyx of the single flower bud is very similar in shape, size and epidermal features to the calyx post-anthetic flowers (Text-fig. 3a, b) and the anatomy of all preserved organs is also identical.

There is no trace of corolla and androecium in the supposed post-anthetic flowers. Corolla and androecium were most likely shed together after flowering, which would also be consistent with stamens that were fused to the corolla. The corolla is five-lobed, with imbricate lobes that are free for most of their length (Text-fig. 3c-e). They appear united at the base, but the preservation does not allow a fully secure conclusion that they were sympetalous.

The internal structures are preserved on one side of the flower bud, but based on the symmetry of the structures that remain, the androecium can be reconstructed as pentamerous and obhaplostemonous with five antepetalous stamens, which are seen near the base of the flower as stout filaments positioned in front of the petal lobes (Text-fig. 3c-e) and near the bud apex as remains of thecae. Smaller structures, interpreted as staminodes, are seen alternating with the petals (Text-fig. 3c-e). Both stamens and staminodes appear to be attached to the corolla near the base (Text-fig. 3f), which is also consistent with the absence of stamens and stamen bases in the post-anthetic flowers.

Normapolles-type pollen, which is very common on the surface of other Mira mesofossils, is also present on Miranthus flowers. However, in addition, two flowers have another kind of pollen on their surface. In both cases, the pollen is about $16 \mu \mathrm{m}$ long and triaperturate with very long colpi that reach almost to the poles (Text-fig. $2 \mathrm{~g}$ ). Unfortunately, the grains are folded and it cannot be established whether the grains are tricolpate or tricolporate. The tectum is foveolate.

The ovary is semi-inferior and unilocular (Text-figs $2 \mathrm{~d}, 4 \mathrm{a}-\mathrm{d}, 5 \mathrm{a}, \mathrm{b}, 6 \mathrm{a}, \mathrm{b}, \mathrm{e})$. The apical portion of the ovary has a slightly protruding ring with stomata-like openings (Text-figs 1c, 2b, c). We think it likely that this zone was nectariferous and that the openings were nectar secreting. In some specimens there appear to be remains of septa in the apical part of the ovary, but these may be invaginations of the ovary wall and they do not reach the centre of the ovary (Text-fig. 5a). The style is long, slender (Text-figs $1 \mathrm{e}, 4 \mathrm{c})$, and distinctly five-angled in cross-section with a vascular bundle that extends for the length of the style in each of the angles (Text-fig. 6c, d). The style is hollow and the stylar canal is wide along its full length (Text-fig. 6d), except near the tip where it is closed (Text-fig. 6c). In some specimens, the style is broken, but the specimens available give no indication of different style lengths and the flower is interpreted as homostylous. Placentation is free and central, with a dome-shaped, almost globose placenta,

alternating with the corolla lobes; note verrucate abaxial surface of calyx lobes (ca) and ovary wall (ow) partly distorted and displaced to one side. f: Longitudinal section (orthoslice yz0567) of flower bud showing ovary wall (ow) and insertion of calyx (ca), corolla (co) and stamens (st) on a hypanthium rim. Specimen, Mira 100-S266059 (a-f). Scale bars = $600 \mu \mathrm{m}(\mathrm{a}, \mathrm{b}), 300 \mu \mathrm{m}(\mathrm{c}-\mathrm{f})$. 

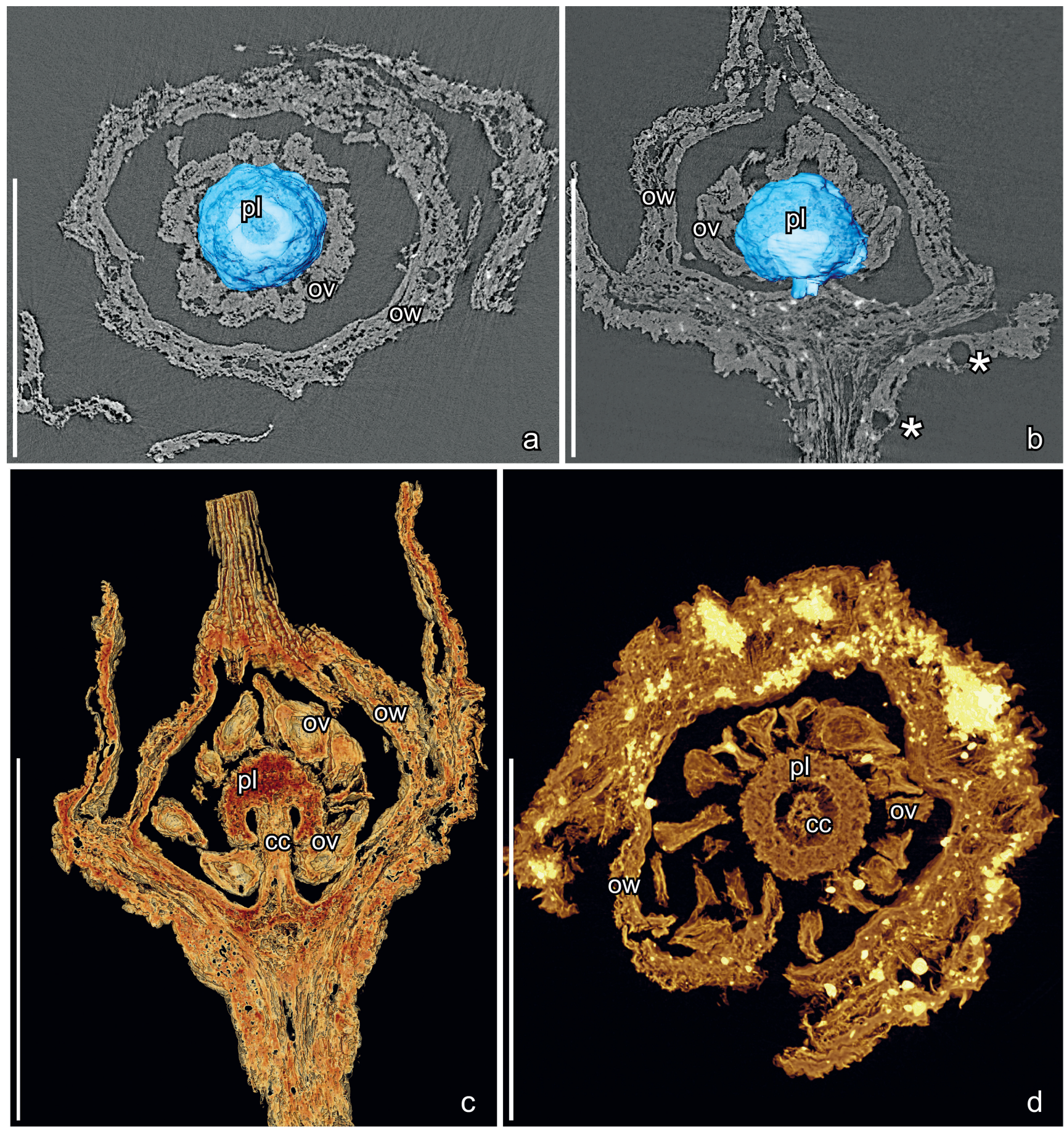

Text-fig. 4. SRXTM images of Miranthus elegans gen. et sp. nov.; Mira locality, Portugal. a, b: Transverse (a) and longitudinal (b) sections of flower showing the ovary wall (ow) and numerous ovules (ov) borne on the mushroom-shaped central globose placenta (pl, blue); placenta shown as a voltex rendering added to orthoslices; note the large openings in the floral tissue (asterisks) interpreted as schizogenous secretory cavities. c, d: Longitudinal (c) and transverse (d) sections of flower (c, volume rendering cut between orthoslice yz0970-1005; d, volume rendering cut between orthoslice xy0780-0820) showing semiinferior ovary (ow, ovary wall) with sepals inserted at the rim of the hypanthium, central column (cc) with mushroom-shaped globose placenta (pl) bearing numerous ovules (ov). Specimens, Mira 100-S153146 (a, b), Mira 100-S170155 (c, d, holotype). Scale bars $=600 \mu \mathrm{m}(\mathrm{a}-\mathrm{d})$.

borne on a central column (Text-figs $4 a-d, 5 a-b, 6 a, b, e)$. Numerous ovules are densely spaced on the placenta, but not immersed in its surface (Text-figs $2 \mathrm{e}, 4 \mathrm{a}-\mathrm{d}, 5 \mathrm{a}-\mathrm{d}, 6 \mathrm{~b}, \mathrm{e})$. Ovules are bitegmic and anatropous, about $0.14 \mathrm{~mm}$ long, with a reticulate seed surface (Text-fig. 2e).

Among the post-anthetic flowers, none has a fully developed fruit. However, some are clearly five-parted, have five valves and are interpreted as young capsules (Text-fig. 1e, f). In one specimen the ovary is split open along one of the valves (Text-fig. 2d). The epidermal cells of the young capsules are small, equiaxial, and often with tiny papillate projections. Stomata occur scattered over the surface of the calyx lobes and pedicel together with smaller openings that are probably trichome bases. Larger openings are irregularly scattered and are interpreted as schizogenous secretory cavities that are sometimes burst (Text-figs 1b, c, 4b). 

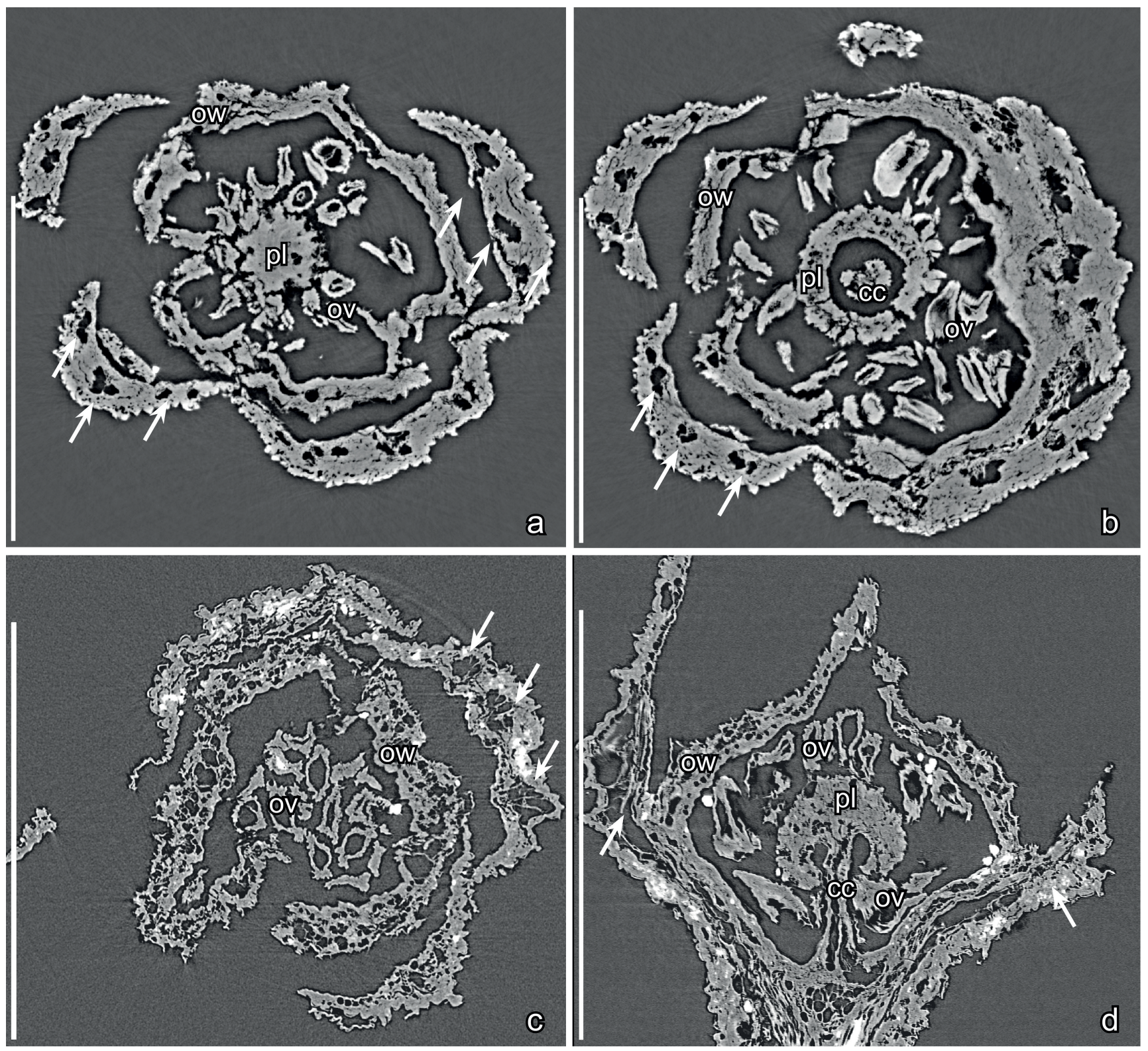

Text-fig. 5. SRXTM images of Miranthus elegans gen. et sp. nov.; Mira locality, Portugal. a, b: Transverse sections of flower (a, orthoslice xy0665 close to the apex of placenta; $b$, orthoslice xy0800 in middle part of placenta) showing remains of calyx with distinct bundles (arrows), ovary wall (ow) and numerous ovules (ov) on the central mushroom-shaped globose placenta (pl) with central column (cc). c: Transverse section of flower (orthoslice xy0620) through perianth and ovary (ow) at a level above the placenta showing ovules (ov) and cellular preservation of the sepal bundles (arrows shown for one sepal); note abaxial surface of sepals with thick-walled epidermal cells, thick cuticle, and fine pointed verrucae. $d$ : Longitudinal section of flower (orthoslice xz0500) showing perigynous position of calyx and semi-inferior ovary (ow, ovary wall) with a central placenta ( $\mathrm{pl}$ ), central column (cc) and numerous ovules (ov); note spiny verrucae on abaxial surface of calyx lobes. Specimens, Mira 100-S153145 (a, b), Mira 100-S170155 (c, d, holotype). Scale bars = 600 $\mu \mathrm{m}(\mathrm{a}-\mathrm{d})$.

\section{Miranthus kvacekii E.M.FriIs, P.R.Crane et K.R.Pedersen sp. nov. \\ Text-fig. 7a-e}

H o l o ty pe. S170157 (Mira sample 100; figured Textfig. $7 \mathrm{a}-\mathrm{e})$.

Plant Fossil Names Registry Number. PFN002673 (for new species).

Repository. Palaeobotanical Collections, Swedish Museum of Natural History, Stockholm, Sweden (S).

E ty mology. In commemoration of Zlatko Kvaček and his outstanding contributions to Cretaceous and Cainozoic angiosperm palaeobotany.
Type locality. Mira $\left(40^{\circ} 25^{\prime} \mathrm{N} ; 08^{\circ} 44^{\prime} 15^{\prime \prime} \mathrm{W}\right)$, about $25 \mathrm{~km}$ south of Aveiro, District of Coimbra, Portugal.

Type stratum and age. "Argilas de Vagos", Late Cretaceous (Campanian/Maastrichtian).

Diagnosis. As for the genus with the following addition: Epidermis of pedicel and outer (abaxial) epidermis of calyx with closely spaced, robust, stiff trichomes.

Dimensions. Length of flower excluding pedicel and corolla: $0.8-1.0 \mathrm{~mm}$; diameter: $0.7-1.0 \mathrm{~mm}$. Length of flower bud with corolla, but excluding the pedicel: $1.5 \mathrm{~mm}$.

Description and comments on the species. The species is based on a single flower bud 

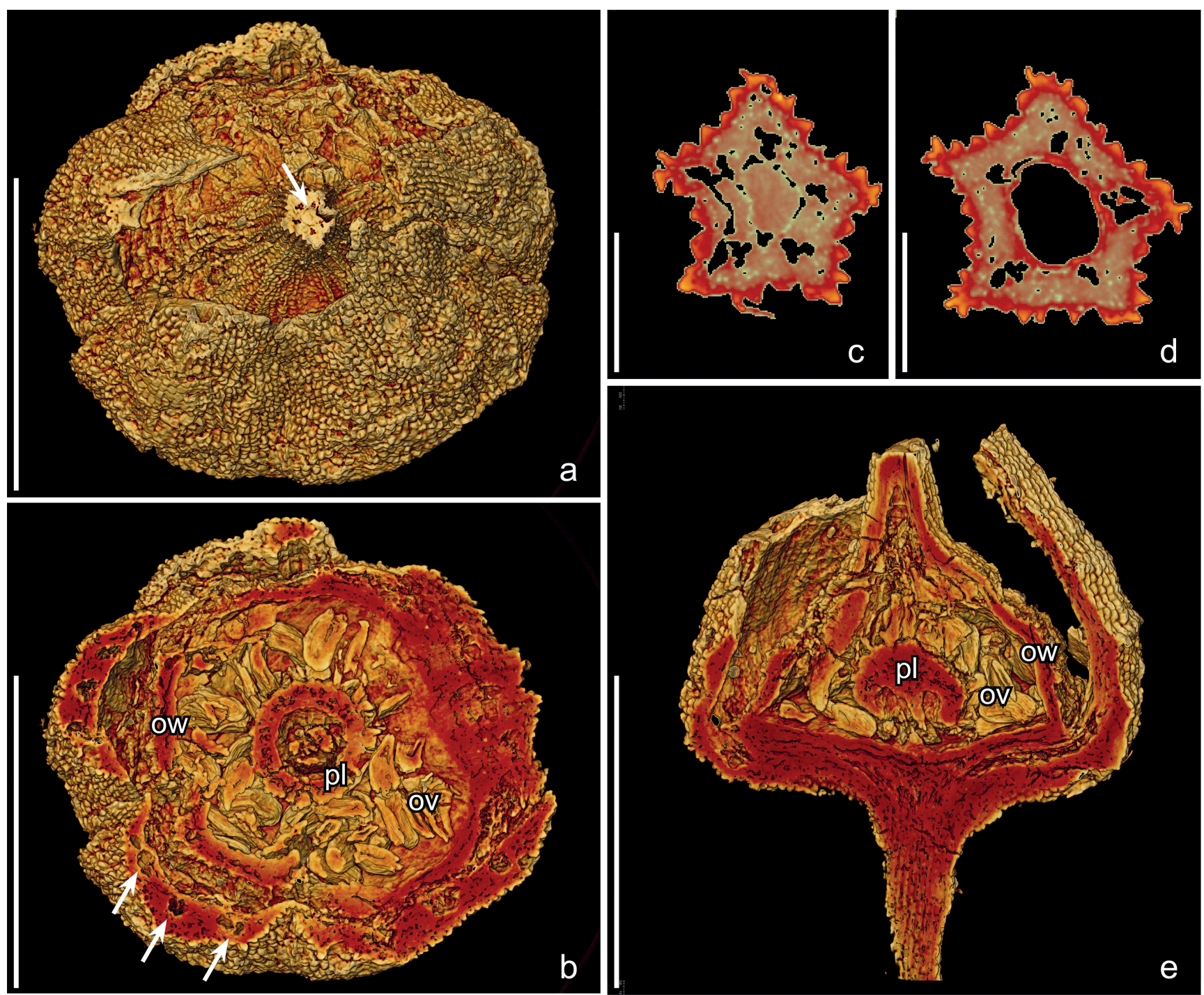

Text-fig. 6. SRXTM images of Miranthus elegans gen. et sp. nov.; Mira locality, Portugal. a: Volume rendering of flower in apical view showing five narrow calyx lobes; note that the apical part of the five-angled style is sealed (arrow). b: Volume rendering of flower (cut at orthoslice xy0796) showing transverse sections of calyx lobes with three distinct bundles indicated by arrows in one of the lobes, ovary wall (ow) and central placenta (pl) bearing numerous ovules (ov). c, d: Transverse sections of style (c, orthoslice xy0153; d, orthoslice xy0222) showing five angled form, sealed near apex (c) and with prominent central canal further farther down (d). e: Volume rendering of flower (cut at orthoslice xz1024) in longitudinal section showing calyx, semi-inferior ovary with ovary wall (ow), and central placenta ( $\mathrm{pl}$ ) bearing numerous ovules (ov). Specimen, Mira 100-S153145 (a-d). Scale bars = $600 \mu \mathrm{m}$ $(\mathbf{a}, \mathbf{b}, \mathbf{e}), 100 \mu \mathrm{m}(\mathbf{c}, \mathbf{d})$.

discovered with Miranthus elegans in the Mira mesofossil flora (Text-fig. 7a-e). The individual floral parts are strongly appressed and somewhat distorted, which impedes a full understanding of the floral structure and organization (Textfig. 7b-e). However, the androecium clearly consists of five stamens. The stamens also apparently alternate with the sepals and are obhaplostemonous (Text-fig. 7d, e). The stamen filaments appear to be fused to the corolla for part of their length, while the anthers are free from the corolla and from each other. Alternating with the filaments are filament-like structures. These are not as distinct as the stamen filaments and interpreted as staminodes (Text-fig. 7e). The flower bud is similar to Miranthus elegans in its characteristic free, dome-shaped placenta (Text-fig. 7b, c) and semi-inferior ovary (Text-fig. $7 b, c)$, but differs in having short, densely spaced trichomes on the outer surface of the calyx lobes, particularly along the margins (Text-fig. 7a). Although scattered trichomes and trichome basis are observed in Miranthus elegans, the trichomes are much finer and less densely spaced.

\section{Five-carpellate capsule assigned to Miranthus Text-fig. 8a-d}

D e s c ription. A single five-carpellate capsular fruit (S156331) was discovered with the Miranthus flowers in the Mira flora (Text-fig. 8a-d). The fruit is subglobose, about $1.6 \mathrm{~mm}$ in diameter with remains of the perianth near the base. The fruit contains many angular seeds, up to about $0.8 \mathrm{~mm}$ long with a bitegmic seed coat with a thin testa and a membranous tegmen (Text-fig. 8c). The placenta is central, free and borne on a central column (Text-fig. 8c, d). The seed surface is reticulate with lumina arranged in longitudinal rows and delimited by slightly raised periclinal walls (Text-fig. 8a, b), similar to those of the ovules in 

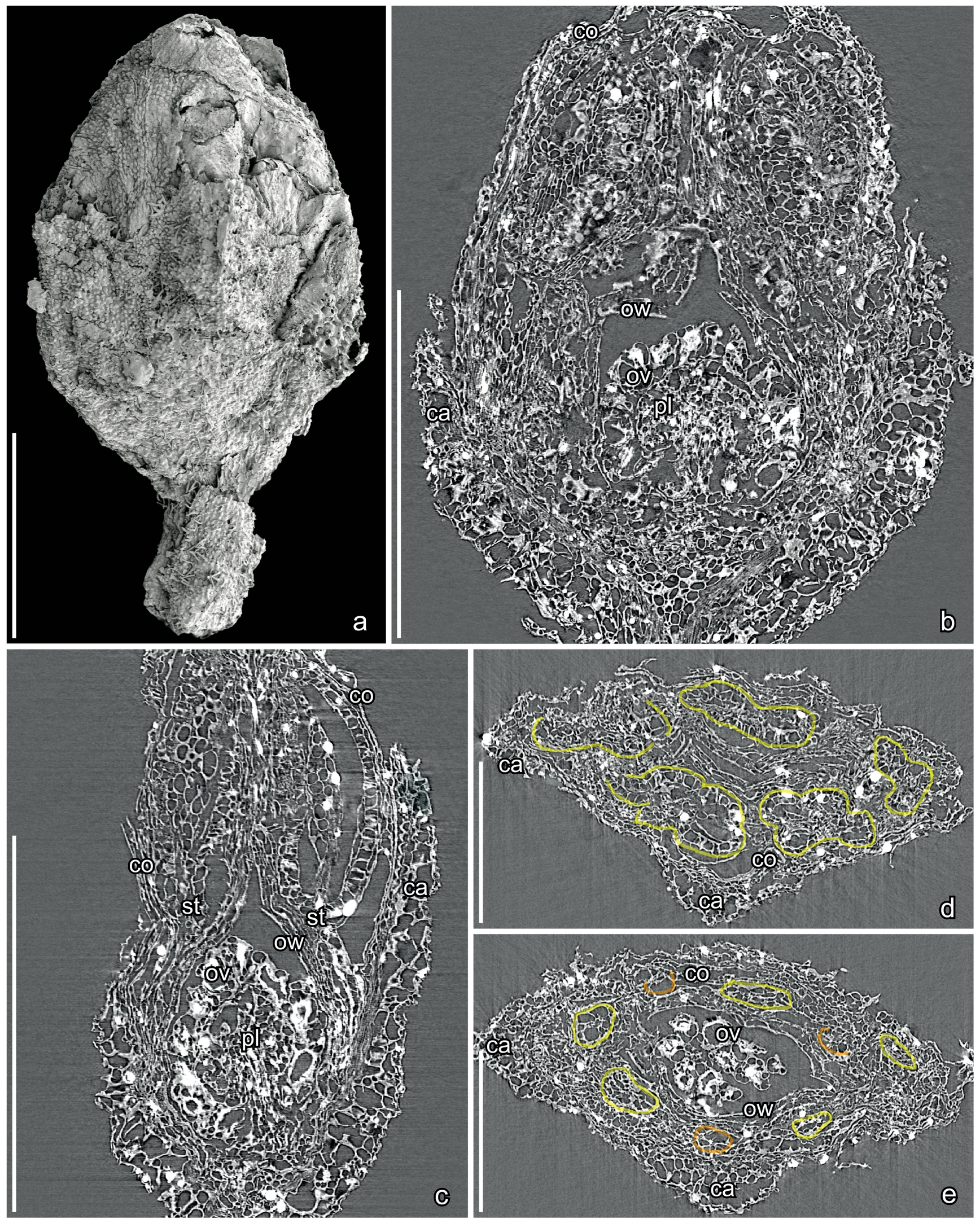

Text-fig. 7. SEM (a) and SRXTM (b-e) images of Miranthus kvacekii sp. nov.; Mira locality, Portugal. a: Lateral view of flower bud showing corolla lobes extending beyond calyx; note surface of pedicel, calyx and corolla with small equiaxial epidermal cells and indumentum of densely spaced, short stiff trichomes. $b$, c: Longitudinal sections through floral bud in two directions perpendicular to each other (a, orthoslice yz1024; b, orthoslice xz0950) showing corolla (co), calyx (ca), stamens (st) and semi-inferior ovary with thin ovary wall (ow) and central mushroom-shaped globose placenta (pl) bearing numerous ovules (ov). d, e: Transverse sections through floral bud above placenta (d, orthoslice xy0915; e, orthoslice xy1095) showing calyx (ca), corolla (co), ovary wall (ow) and ovules (ov); yellow outlines indicate the positions of anthers (d) and filaments (e); orange outlines indicate the position of three of the possible staminodes. Specimen, Mira 100-S170157 (a-e, holotype). Scale bars $=600 \mu \mathrm{m}(\mathrm{a}-\mathrm{c}), 300 \mu \mathrm{m}(\mathrm{d}, \mathrm{e})$. 

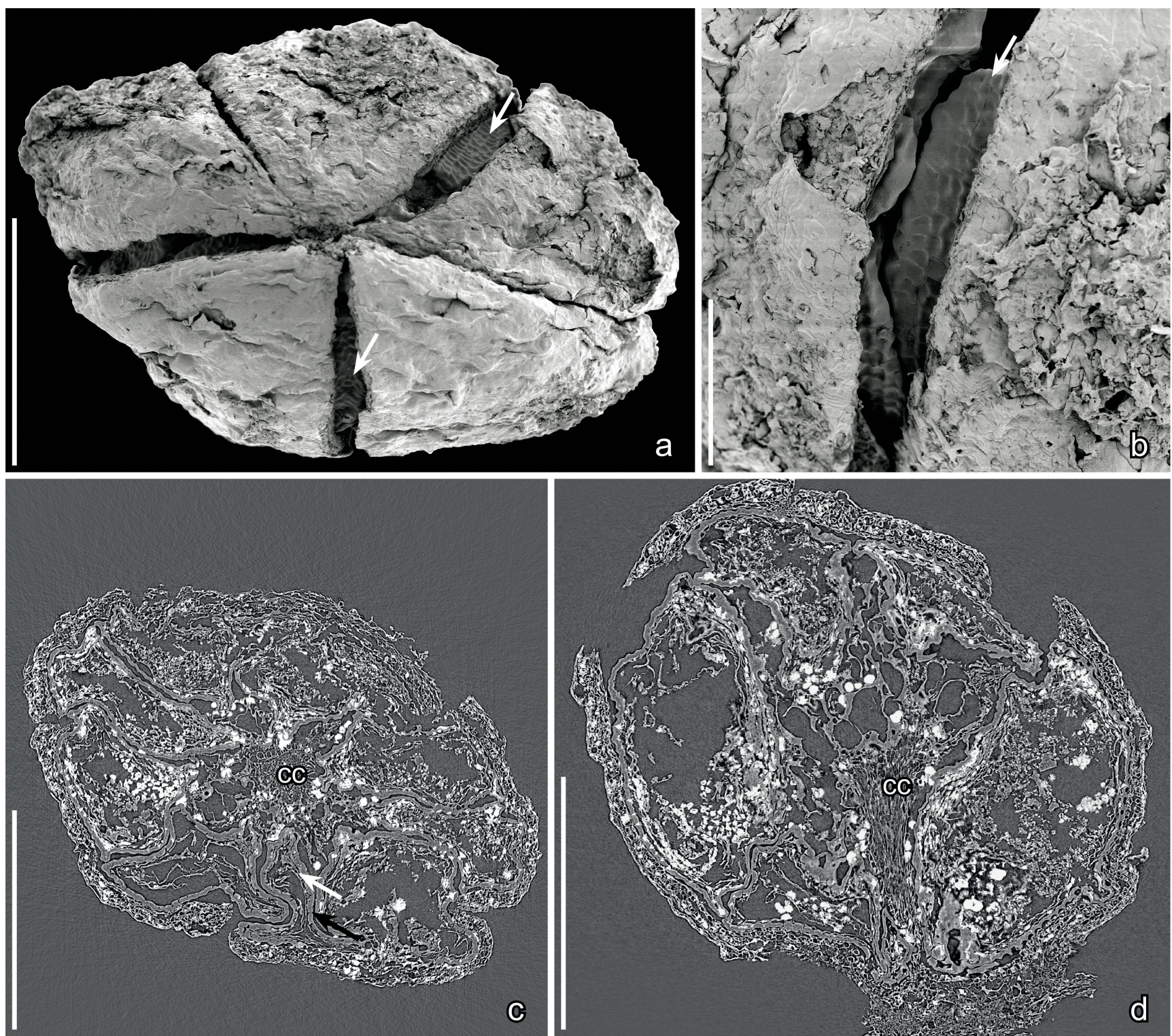

Text-fig. 8. SEM (a, b) and SRXTM (c, d) images of fruit associated with Miranthus elegans and Miranthus kvacekii; Mira locality, Portugal. a: Apical view of capsular fruit with five, partly open valves revealing the enclosed reticulate seeds (arrows). b: Detail of fruit wall showing an enclosed seed (arrow). c: Transverse section (orthoslice xy1200) of fruit showing central column (cc) of placenta and numerous angular and bitegmic seeds; note that the outer integument (black arrow) is thicker than inner integument (white arrow). d: Longitudinal section (orthoslice yz1239) of fruit showing perigynous attachment of calyx, central column (cc) of the placenta and sections through seeds. Specimen, Mira 99-S156331 (a-d). Scale bars = $600 \mu \mathrm{m}$ (a, c, d), $200 \mu \mathrm{m}$ (b).

flowers of Miranthus. Because of this similarity and because Miranthus is the only flower in the Mira mesofossil flora with five carpels, the capsule is interpreted as a mature fruit of either Miranthus elegans or M. kvacekii. Unfortunately, details of the epidermis of the calyx are not known, which precludes assignment at the species level.

\section{Discussion: Systematic relationships of Miranthus}

Characters of the Miranthus flowers clearly place the fossil taxon in the primuloid clade, which is firmly nested among the Ericales (e.g., Anderberg et al. 2002, Schönenberger et al. 2005). In most classifications the primuloid clade comprises four groups recognised either as families of the order Primulales (Maesaceae, Theophrastaceae,
Primulaceae, Myrsinaceae; Anderberg and Ståhl 1995, Anderberg et al. 1998a, 2000a, Källersjö et al. 2000, Schönenberger et al. 2005) or as subfamilies of the family Primulaceae (Maesoideae, Theophrastoideae, Primuloideae, Myrsinoideae; APGIII 2009). A fifth, monogeneric lineage, Samolaceae/Samoloideae, is now usually treated as a tribe, Samoleae, within the Theophrastaceae/Theophrastoideae group (e.g., Källersjö et al. 2000, Caris and Smets 2004). We here use the inclusive definition of Primulaceae s. 1.

Extensive studies on extant primuloids by Anderberg and colleagues (e.g., Anderberg and Ståhl 1995, Anderberg et al. 1998a, b, 2000a, b, 2007, Källersjö et al. 2000, Källersjö and Ståhl 2003, Wanntorp and Anderberg 2011), as well as by other researchers (e.g., Caris et al. 2000, Ma and Saunders 2003, Caris and Smets 2004, Morozowska et al. 2020), have been pivotal for our comparative studies and for recognizing the affinities of the fossil flowers. Relationships among 


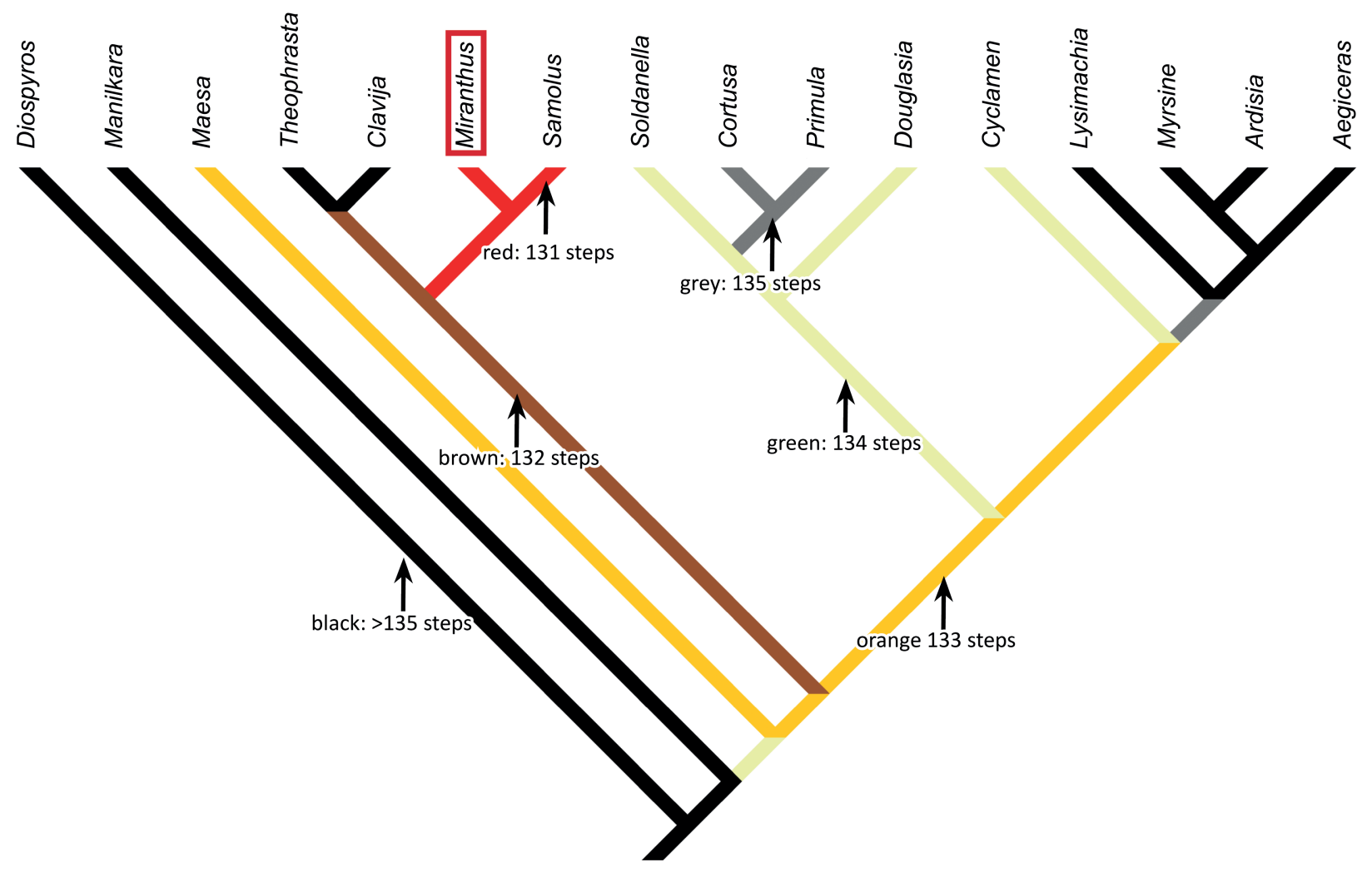

Text-fig. 9. Phylogenetic tree indicating the number of required character state changes (steps) under parsimony for various positions of Miranthus gen. nov. in a molecular based backbone tree (see material and methods for additional details).

the main primuloid lineages are well supported based on phylogenetic analyses of both morphological and molecular data. The monogeneric Maesoideae is resolved as the sister lineage to the remaining taxa, with Theophrastoideae resolved as sister to a well-supported PrimuloideaeMyrsinoideae clade (Källersjö et al. 2000, Bremer et al. 2002, Schönenberger et al. 2005). Within Theophrastoideae, the monogeneric Samoleae are sister to all other members of the subfamily.

Shared features for Miranthus and the Primulaceae include the pentamerous and isomerous organisation of the flowers, persistent calyx, haplostemonous androecium and the highly characteristic free central and dome-shaped placenta. Among Ericales, a free central placenta is known only for the Primulaceae and is a clear synapomorphy for the group (Schönenberger et al. 2005).

Few floral features distinguish the various primuloid lineages and a separation of the lineages based on floral morphology is only poorly supported. As noted by Caris and Smets (2004) "it seems that no unambiguous morphological synapomorphies can be found that justify a position of Samolus in either Primulaceae or Theophrastaceae", but a position as sister to Theophrastoideae is well supported by molecular data (Källersjö and Ståhl 2003). Nevertheless, the semi-inferior ovary of Miranthus flowers, and the presence of staminodes alternating with the corolla lobes, are important distinctive floral features. Furthermore, among extant primuloids, a semi-inferior ovary is known only for Maesa Forssk. and Samolus L., and staminodes are present only in Maesa, the genera of Theophrastoideae (including Samolus), and Soldanella L. of the Primuloideae (Anderberg and Ståhl 1995, Anderberg et al. 1998a). A nectariferous zone on the upper part of the ovary, referred to as "nectarostomata on the flanks of the ovary" by Caris and Smets (2004), is a further feature shared with Maesa and Samolus that is not present in other primuloid taxa (Caris et al. 2000, Caris and Smets 2004). Miranthus thus appears to be nested securely in the primuloid clade.

Maesa comprises about 150 species of tropical and subtropical vines, shrubs, and trees in the Old World (Anderberg et al. 2000a), whereas species of Samolus are herbaceous and less diverse with about twelve species. Four or five species of Samolus occur in the southern United States, Cuba and Mexico, and one species (Samolus valerandi L.) is cosmopolitan in distribution. The remaining species are restricted to the Southern Hemisphere, with three species in South America, four in Australia and Tasmania, and one in South Africa (Ståhl 2004a, Wanntorp and Anderberg 2011). Maesa is distinguished from Miranthus and all other primuloid taxa by the presence of two bracteoles immediately under the calyx. Miranthus and other primuloids display the likely plesiomorphic condition in which such bracteoles are lacking (Anderberg et al. 2000a). Miranthus is also more like Samolus in having a long and slender pedicel.

The close relationship of Miranthus and Samolus suggested by their morphological similarities is supported by the results of the phylogenetic analysis (Text-fig. 9). The most parsimonious position of Miranthus is as sister to Samolus in the Theophrastoideae (131 steps). However, a sister group relationship to Theophrastoideae, or a position as sister to Clavija Ruz et PAv. + Theophrasta L., is only one step longer (132 steps), while a sister group relationship 
to either Clavija or Theophrasta is less parsimonious (136 steps). A sister group relationship to Myrsinoideae is also only two steps less parsimonious than the MiranthusSamolus relationship, as also is a sister group relationship to Theophrastoideae + Primuloideae + Myrsinoideae, to Primuloideae + Myrsinoideae, and to Maesa (133 steps). All other positions are less parsimonious (134 steps or more; Text-fig. 9).

\section{Conclusions: phytogeography and ecology}

The subfamily Theophrastoideae includes mainly shrubs and small trees distributed from northern Mexico and southern Florida to southern Brazil and northern Paraguay, with Samolus as the principal exception (see above and Ståhl 2004b, Wanntorp and Anderberg 2011). Based on a fossil calibrated phylogenetic analysis Rose et al. (2018) suggested that Theophrastoideae originated about 70 million years ago in the Neotropics, and that occurrences outside the Neotropics, including the distribution of Samolus, reflect subsequent and probably relatively recent migration. The discovery of Miranthus from Portugal in the Late Cretaceous, combined with the disjunct distribution of Samolus in the Southern Hemisphere, suggests a more complex biogeographic history, which also recalls the likely close relationship between the Late Cretaceous fossil flower Silvianthemum E.M.FriIs from southern Sweden and the Southern Hemisphere genus Quintinia A.DC. (Friis 1990, Friis et al. 2013). Such results suggest the need for caution in interpreting the origin of present-day phytogeographic patterns without the benefit of palaeobotanical data. Miranthus, and other fossils imply significant extinction in the early history of Ericales during the Late Cretaceous. The role that such extinctions may have played in the origin of present day biogeographic patterns deserves more detailed consideration.

A probable close relationship between Miranthus and Samolus is also of ecological interest. Most species of Samolus inhabit wetlands, and many grow near the seashore in salt marshes or brackish ponds (Ståhl 2004a). The quality of preservation of Miranthus, including little damaged, delicate floral structures, suggests that the fossils were deposited close to the environment in which they lived. The flowers of Miranthus were discovered in sediments with clear marine influence. Like Samolus, Miranthus may have been growing in coastal plains or estuaries partially influenced by marine conditions. Miranthus thus provides an example not only of relative morphological stasis, but may also indicate the longterm persistence of a particular habitat preference established early in the diversification of Ericales.

\section{Acknowledgements}

We thank the Paul Scherrer Institut, Villigen, Switzerland, for provision of synchrotron radiation beamtime at the TOMCAT beamline X02DA of the Swiss Light Source. We are also grateful to Federica Marone for her help at the beamline (projects 20060846, 20060151, 20080872, 20100167, 20190071 to P. C. J. Donoghue, S. Bengtson, M. Rücklin and E. M. Friis) and Anna Lindström for help with the SRXTM analyses. P. S. Herendeen and S. R. Manchester are thanked for helpful comments on the manuscript. Support for this research was also obtained from the Swedish Research Council (2014-5228 to E. M. Friis) and from the Oak Spring Garden Foundation.

\section{References}

Anderberg, A. A., Manns, U., Källersjö, M. (2007): Phylogeny and floral evolution of the Lysimachieae (Ericales, Myrsinaceae): Evidence from ndhF sequence data. Willdenowia, 37: 407-421. https://doi.org/10.3372/wi.37.37202

Anderberg, A. A., Rydin, C., Källersjö, M. (2002): Phylogenetic relationships in the order Ericales s. 1.: Analyses of molecular data from five genes from the plastid and mitochondrial genomes. - American Journal of Botany, 89: 677-687.

https://doi.org/10.3732/ajb.89.4.677

Anderberg, A. A., Ståhl, B. (1995): Phylogenetic interrelationships in the order Primulales, with special emphasis on the family circumscriptions. - Canadian Journal of Botany, 73: 1699-1730. https://doi.org/10.1139/b95-184

Anderberg, A. A., Ståhl, B., Källersjö, M. (1998a): Phylogenetic relationships in the Primulales inferred from rbcL sequence data. - Plant Systematics and Evolution, 211: 93-102. https://doi.org/10.1007/BF00984914

Anderberg, A. A., Ståhl, B., Källersjö, M. (2000a): Maesaceae, a new primuloid family in the order Ericales s. 1. - Taxon, 49: 183-187. https://doi.org/10.2307/1223834

Anderberg, A. A., Trift, I., Källersjö, M. (1998b): On the systematic position of the genus Coris (Primulaceae). Nordic Journal of Botany, 18: 203-207. https://doi.org/10.1111/j.1756-1051.1998.tb01872.x

Anderberg, A. A., Trift, I., Källersjö, M. (2000b): Phylogeny of Cyclamen L. (Primulaceae): Evidence from morphology and sequence data from the internal transcribed spacers of nuclear ribosomal DNA. - Plant Systematics and Evolution, 220: 147-160. https://doi.org/10.1007/BF00985043

Antunes, M. T., Broin, F. (1988): Le Crétacé terminal de Beira Litoral, Portugal: remarques stratigraphiques et écologiques, étude complémentaire de Rosasia soutoi (Chelonii, Bothremydidae). - Ciências da Terra, 9: 153-200.

APGIII (2009): An update of the Angiosperm Phylogeny Group classification for the orders and families of flowering plants: APG III. - Botanical Journal of the Linnean Society, 161: 105-121. https://doi.org/10.1111/j.1095-8339.2009.00996.x

Barbosa, B. P. (1981): Carta geológica de Portugal na escala de 1/50000. Notícia explicativa da folha $16-\mathrm{C}$ Vagos [Geological map of Portugal on the scale 1/50000. Explanatory notes to the map 16-C Vagos]. - Serviços Geológicos de Portugal, Lisbon. (in Portugese).

Beauvais, M., Berthou, P.-Y., Lauverjat, J. (1975): Le gisement Campanien de Mira (Beira Litorale, Portugal): 
sédimentologie, micropaléonotologie, révision des Madréporaires. - Comunicações dos Serviços Geológicos de Portugal, 59: 37-58.

Bremer, B., Bremer, K., Heidari, N., Erixon, P., Olmstead, R. G., Anderberg, A. A., Källersjö, M., Barkhordarian, E. (2002): Phylogenetics of asterids based on 3 coding and 3 non-coding chloroplast DNA markers and the utility of non-coding DNA at higher taxonomic levels. - Molecular Phylogenetics and Evolution, 24: 274-301. https://doi.org/10.1016/S1055-7903(02)00240-3

Bernardes, C. A., Corrochano, A. (1987): A sedimentologia da "Formação arenitos e argila de Aveiro": cretácico superior, bacia ocidental portuguesa [On the sedimentology of the "Formação arenitos e argila de Aveiro": Late Cretaceous of the western Portuguese Basin]. - Geociěncias, 2: 9-26. (in Portugese)

Caris, P., Ronse Decraene, L. P., Smets, E., Clinckemaillie, D. (2000): Floral development of three Maesa species, with special emphasis on the position of the genus within Primulales. - Annals of Botany, 86: 87-97. https://doi.org/10.1006/anbo.2000.1163

Caris, P., Smets, E. (2004): A floral ontogenetic study on the sister group relationship between the genus Samolus (Primulaceae) and the Theophrastaceae. - American Journal of Botany, 91: 627-643.

https://doi.org/10.3732/ajb.91.5.627

Conwentz, H. (1886): Die Flora des Bernsteins. Zweiter Band - Die Angiospermen des Bernsteins. - Commissions-Verlag von Wilhelm Engelmann, Danzig, xii + 140 pp. +13 pls. https://doi.org/10.5962/bhl.title.29891

Crane, P. R., Friis, E. M., Pedersen, K. R. (1995): The origin and early diversification of angiosperms. - Nature, 374: 27-33. https://doi.org/10.1038/374027a0

Crane, P. R., Lidgard, S. H. (1989): Angiosperm diversification and paleolatitudinal gradients in Cretaceous floristic diversity. - Science, 246: 675-678.

https://doi.org/10.1126/science. 246.4930 .675

Crepet, W. L. (1996): Timing in the evolution of derived floral characters: Upper Cretaceous (Turonian) taxa with tricolpate and tricolpate-derived pollen. - Review of Palaeobotany and Palynology, 90: 339-359. https://doi.org/10.1016/0034-6667(95)00091-7

Crepet, W. L., Nixon, K. C., Daghlian, C. P. (2013): Fossil Ericales from the Upper Cretaceous of New Jersey. International Journal of Plant Sciences, 174: 572-584. https://doi.org/10.1086/668689

Crepet, W. L., Nixon, K. C, Gandolfo, M. A. (2004): Fossil evidence and phylogeny: the age of major angiosperm clades based on mesofossil and macrofossil evidence from Cretaceous deposits. - American Journal of Botany, 91: 1666-1682. https://doi.org/10.3732/ajb.91.10.1666

Crepet, W. L., Nixon, K. C, Weeks, A. (2018): Mid-Cretaceous angiosperm radiation and an asterid origin of bilaterality: diverse and extinct "Ericales" from New Jersey. - American Journal of Botany, 105: 1412-1423. https://doi.org/10.1002/ajb2.1131

Dinis, J. L., Rey, J., Cunha, P. P., Callapez, P., Pena Dos Reis, R. (2008): Stratigraphy and allogenic controls of the western Portugal Cretaceous: an updated synthesis. Cretaceous Research, 29: 772-780.

https://doi.org/10.1016/j.cretres.2008.05.027

Doyle, J. A., Hickey, L. J. (1976): Pollen and leaves from the mid-Cretaceous Potomac Group and their bearing on early angiosperm evolution. - In: Beck, C. B. (ed.), Origin and Early Evolution of Angiosperms. Columbia University Press, New York, pp. 139-206.

Friis, E. M. (1983): Upper Cretaceous (Senonian) floral structures of juglandalean affinity containing Normapolles pollen. - Review of Palaeobotany and Palynology, 39: $161-188$. https://doi.org/10.1016/0034-6667(83)90015-5

Friis, E. M. (1985): Actinocalyx gen. nov., sympetalous angiosperm flowers from the Upper Cretaceous of southern Sweden. - Review of Palaeobotany and Palynology, 45: 171-183. https://doi.org/10.1016/0034-6667(85)90001-6

Friis, E. M. (1990): Silvianthemum suecicum gen. et sp. nov., a new saxifragalean flower from the Late Cretaceous of Sweden. - Biologiske Skrifter, Kongelige Danske videnskabernes Selskab, 36: 1-35.

Friis, E. M., Crane, P. R., Pedersen, K. R. (2011): Early flowers and angiosperm evolution. - Cambridge University Press, Cambridge, $\mathrm{x}+585 \mathrm{pp}$. https://doi.org/10.1017/CBO9780511980206

Friis, E. M., Crane, P. R., Pedersen, K. R. (2018): Rightcania and Kvacekispermum: Early Cretaceous seeds from eastern North America and Portugal provide further evidence of the early chloranthoid diversification. - Fossil Imprint, 74: 65-76.

https://doi.org/10.2478/if-2018-0006

Friis, E. M., Crane, P. R., Pedersen, K. R., Bengtson, S., Donoghue, P. C. J., Grimm, G. W., Stampanoni, M. (2007): Phase contrast enhanced synchrotron-radiation X-ray analyses of Cretaceous seeds link Gnetales to extinct Bennetttiales. - Nature, 450: 549-552. https://doi.org/10.1038/nature06278

Friis, E. M., Crane, P. R., Pedersen, K. R., Marone, F. (2021): Synchrotron radiation $\mathrm{X}$-ray tomographic microscopy datasets for primuloid flowers from the Late Cretaceous of Portugal; on-line available datasets. - PSI Public Data Repository, operated by Paul Scherrer Institute, Villigen, Switzerland.

https://doi.org/10.16907/b97fe9b1-27f0-44ff-ab63$76 \mathrm{c} 6054 \mathrm{fbab} 9$

Friis, E. M., Crane, P. R., Pedersen, K. R., Stampanoni, M., Marone, F. (2015): Exceptional preservation of tiny embryos documents seed dormancy in early angiosperms. - Nature, 528: 551-554. https://doi.org/10.1038/nature16441

Friis, E. M., Marone, F., Pedersen, K. R., Crane, P. R., Stampanoni, M. (2014): Three-dimensional visualization of fossil flowers, fruits, seeds and other plant remains using synchrotron radiation X-ray tomographic microscopy (SRXTM): New insights into Cretaceous plant diversity. - Journal of Paleontology, 88: 684-701. https://doi.org/10.1666/13-099

Friis, E. M., Pedersen K. R., Crane, P. R. (1992): Esgueiria gen. nov., fossil flowers with combretaceous features from the Late Cretaceous of Portugal. - Biologiske 
Skrifter, Kongelige Danske videnskabernes Selskab, 41: $1-45$.

Friis, E. M., Pedersen, K. R., Crane, P. R. (2006a): Cretaceous angiosperm flowers: Innovation and evolution in plant reproduction. - Palaeogeography, Palaeoclimatology, Palaeoecology, 232: 251-293.

https://doi.org/10.1016/j.palaeo.2005.07.006

Friis, E. M., Pedersen, K. R., Crane, P. R. (2010): Cretaceous diversification of angiosperms in the western part of the Iberian Peninsula. - Review of Palaeobotany and Palynology, 162: 341-361. https://doi.org/10.1016/j.revpalbo.2009.11.009

Friis, E. M., Pedersen, K. R., Crane, P. R. (2016): The emergence of core eudicots: new floral evidence from the earliest Late Cretaceous. - Proceedings of the Royal Society, B, 283: 20161325 (9 pp.). https://doi.org/10.1098/rspb.2016.1325

Friis, E. M., Pedersen, K. R., Endress, P. K. (2013): Floral structure of extant Quintinia (Paracryphiales, campanulids) compared with the Late Cretaceous Silvianthemum and Bertilanthus. - International Journal of Plant Sciences, 174: 647-664. https://doi.org/10.1086/669908

Friis, E. M., Pedersen, K. R., Schönenberger, J. (2003): Endressianthus, a new Normapolles producing plant genus of fagalean affinity from the Late Cretaceous of Portugal. - International Journal of Plant Sciences, 164(5 Suppl.): S201-S223. https://doi.org/10.1086/376875

Friis, E. M., Pedersen, K. R., Schönenberger, J. (2006b): Normapolles plants: A prominent component of the Cretaceous rosid diversification. - Plant Systematics and Evolution, 260: 107-140. https://doi.org/10.1007/s00606-006-0440-y

Göppert, H. R., Berendt, G. C. (1845): Der Bernstein und die in ihm befindlichen Pflanzenreste der Vorwelt. Nicolaische Buchhandlung, Berlin, iv +125 pp. +7 pls.

Herendeen, P. S., Friis, E. M., Pedersen, K. R., Crane, P. R. (2017): Palaeobotanical Redux: How Old are the Angiosperms? - Nature Plants, 3: 1-8. https://doi.org/10.1038/nplants.2017.15

Hickey, L. J., Doyle, J. A. (1977): Early Cretaceous fossil evidence for angiosperm evolution. - The Botanical Review, 43: 2-104. https://doi.org/10.1007/BF02860849

Källersjö, M., Bergqvist, G., Anderberg, A. A. (2000): Generic realignment in primuloid families of the Ericales s. 1.: a phylogenetic analysis based on DNA sequences from three chloroplast genes and morphology. - American Journal of Botany, 87: 1325-1341. https://doi.org/10.2307/2656725

Källersjö, M., Ståhl, B. (2003): Phylogeny of Theophrastaceae (Ericales s. lat.). - International Journal of Plant Sciences, 164: 579-591. https://doi.org/10.1086/375317

Keller, J. A., Herendeen, P. S., Crane, P. R. (1996): Fossil flowers and fruits of the Actinidiaceae from the Campanian (Late Cretaceous) of Georgia. - American Journal of Botany, 83: 528-541.

https://doi.org/10.1002/j.1537-2197.1996.tb12733.x
Knobloch, E., Mai, D. H. (1986): Monographie der Früchte und Samen in der Kreide von Mitteleuropa. - Rozpravy Ústředního ústavu geologického, 47: 1-219.

Li, H. (2005): Early Cretaceous Sarraceniacean-like Pitcher Plants from China. - Acta Botanica Gallica, 152: 227-234. https://doi.org/10.1080/12538078.2005.10515473

Ma, O. S. W., Saunders, R. M. K. (2003): Comparative floral ontogeny of Maesa (Maesaceae), Aegiceras (Myrsinaceae) and Embelia (Myrsinaceae): taxonomic and phylogenetic implications. - Plant Systematics and Evolution, 243: 39-58. https://doi.org/10.1007/s00606-003-0062-6

Maddison, W. P., Maddison, D. R. (2017): Mesquite: a modular system for evolutionary analysis. - Version 3.2. http://mesquiteproject.org

Magallón, S., Crane, P. R., Herendeen, P. S. (1999): Phylogenetic pattern, diversity, and diversification of eudicots. - Annals of the Missouri Botanical Garden, 86: 297-372.

https://doi.org/10.2307/2666180

Manchester, S. R., Dilcher, D. L., Judd, W. S., Corder, B., Basinger, J. F. (2018): Early eudicot flower and fruit: Dakotanthus gen. nov. from the Cretaceous Dakota Formation of Kansas and Nebraska, USA. - Acta Palaeobotanica, 581: 27-40. https://doi.org/10.2478/acpa-2018-0006

Martínez-Millán, M., Crepet, W. L., Nixon, K. C. (2009): Pentapetalum trifasciculandricus gen. et sp. nov., a thealean fossil flower from the Raritan Formation, New Jersey, USA (Turonian, Late Cretaceous). - American Journal of Botany, 96: 933-949. https://doi.org/10.3732/ajb.0800347

Morozowska, M., Freitas, M. F., Luna, B. N., Toni, K. L. G. D. (2020): Comparative micromorphology and anatomy of seeds and endocarps of selected Primulaceae and their systematic implications. - Plant Systematics and Evolution, 306: 74 (19 pp.). https://doi.org/10.1007/s00606-020-01699-z

Nixon, K. C., Crepet, W. L. (1993): Late Cretaceous fossil flowers of ericalean affinity. - American Journal of Botany, 80: 616-623. https://doi.org/10.1002/j.1537-2197.1993.tb15230.x

Rose, J. P., Kleist, T. J., Löfstrand, S. D., Drew, B. T., Schönenberger, J., Sytsma, K. J. (2018): Phylogeny, historical biogeography, and diversification of angiosperm order Ericales suggest ancient Neotropical and East Asian connections. - Molecular Phylogenetics and Evolution, 122: 59-79. https://doi.org/10.1016/j.ympev.2018.01.014

Schönenberger, J., Anderberg, A. A., Sytsma, K. J. (2005): Molecular phylogenetics and patterns of floral evolution in the Ericales. - International Journal of Plant Sciences, 166: 265-288. https://doi.org/10.1086/427198

Schönenberger, J., von Balthazar, M., Takahashi, M., Xiao, X., Crane, P. R., Herendeen, P. S. (2012): Glandulocalyx upatoiensis, a fossil flower of Ericales (Actinidiaceae/ Clethraceae) from the Late Cretaceous (Santonian) of Georgia, USA. - Annals of Botany, 109: 921-936. https://doi.org/10.1093/aob/mcs009 
Schönenberger, J., Friis, E. M. (2001): Fossil flowers of ericalean s. 1. affinity from the Late Cretaceous of southern Sweden. - American Journal of Botany, 88: 467-480. https://doi.org/10.2307/2657112

Schönenberger, J., Pedersen, K. R., Friis, E. M. (2001): Normapolles flowers of fagalean affinity from the Late Cretaceous of Portugal. - Plant Systematics and Evolution, 226: 205-230. https://doi.org/10.1007/s006060170066

Sims, H. J., Herendeen, P. S., Lupia, R., Christopher, R. A., Crane, P. R. (1999): Fossil flowers with Normapolles pollen from the Late Cretaceous of southeastern North America. - Review of Palaeobotany and Palynology, 106: $131-151$.

https://doi.org/10.1016/S0034-6667(99)00008-1

Stampanoni, M., Groso, A., Isenegger, A., Mikuljan, G., Chen, Q., Bertrand, A., Henein, S., Betemps, R., Frommherz, U., Bohler, P., Meister, D., Lange, M., Abela, A. (2006): Trends in synchrotron-based tomographic imaging: the SLS experience. - In: Bonse, U. (ed.), Developments in X-Ray Tomography V. Proceedings of SPIE-
The International Society for Optical Engineering, San Diego, 6318: 63180M (14 pp.). https://doi.org/10.1117/12.679497

Ståhl, B. (2004a): Samolaceae. - In: Kubitzki, K. (ed.), The Families and Genera of Vascular Plants. VI. Flowering Plants, Dicotyledons - Celastrales, Oxalidales, Rosales, Cornales, Ericales. Springer-Verlag, Berlin, Heidelberg, New York, pp. 387-389. https://doi.org/10.1007/978-3-662-07257-8_40

Ståhl, B. (2004b): Theophrastaceae. - In: Kubitzki, K. (ed.), The Families and Genera of Vascular Plants. VI. Flowering Plants, Dicotyledons - Celastrales, Oxalidales, Rosales, Cornales, Ericales. Springer-Verlag, Berlin, Heidelberg, New York, pp. 472-478. https://doi.org/10.1007/978-3-662-07257-8_50

Wanntorp, L., Anderberg, A. A. (2011): Evolution and diversification of brook weeds (Samolus, Samolaceae, Ericales). - International Journal of Plant Sciences, 172: 250-266.

https://doi.org/10.1086/657647 